\title{
A rapid method for estimating mercury in undigested biological samples
}

\author{
L. MAGOS AND A. A. CERNIK
}

Toxicology Research Unit, M.R.C. Laboratories, Woodmansterne Road, Carshalton, Surrey and Department of Employment and Productivity, H.M. Factory Inspectorate, Baynards House, 1 Chepstow Place, London, W.2

\begin{abstract}
Magos, L., and Cernik, A. A. (1969). Brit. J. industr. Med., 26, 144-149. A rapid method for estimating mercury in undigested biological samples. A method has been developed for estimating mercury in biological samples using an ultraviolet mercury detector, after liberating the mercury from the urine and other biological samples by a simple chemical method. The overall time for one estimation is less than two minutes, and no special skills are required to operate the technique.

The principle of the method is that stannous chloride at high $p \mathrm{H}$ liberates mercury from sulphhydryl bonds and converts the liberated mercury into volatile metallic mercury which is subsequently estimated by an ultraviolet photometer. Stannous chloride is added to the acidified sample, and the presence of extra cysteine ensures that no appreciable amount of mercury is lost before the reaction is triggered by the addition of excess sodium hydroxide. The standard solution of mercury developed is stable for months and behaves in the reaction like urine, and, because of its stability, the instrument can be standardized with it frequently and conveniently.
\end{abstract}

The aim of any development in the instrumentation of analytical procedures is either to increase sensitivity and accuracy or to reduce the time and work required. Ultraviolet mercury detectors fully satisfied both conditions when used for the estimation of atmospheric mercury but not when used with conventional laborious procedures for the estimation of mercury in biological samples (Monkman, Maffett, and Doherty, 1956; Jacobs, Yamaguchi, Goldwater, and Gilbert, 1960; Kudsk, 1965). Lindström (1959) tried to simplify the method, but the accuracy of his method depended on several factors needing special attention.

Clearly there was a need for a rapid and simple technique for preparing the mercury for estimation by ultraviolet photometer. The technique had to satisfy the following requirements: the release of mercury from the sample must be prompt and timed; and the standard solution used for calibration must release mercury like urine.
This paper describes a method for the release of mercury from biological samples by a chemical reaction and its subsequent estimation by an ultraviolet photometer. The principle of the reaction is that stannous chloride at high $p \mathrm{H}$ liberates mercury from sulphhydryl bonds and converts the liberated mercury into volatile metallic mercury. Stannous chloride is added to the acidified sample, and the presence of extra cysteine ensures that no appreciable amount of mercury is lost before the reaction is triggered by the addition of excess sodium hydroxide. The method does not estimate organomercurials, i.e., compounds with $\mathrm{Hg}-\mathrm{C}$ bond, and so cannot be used to measure exposure to them as they are excreted at least in part with $\mathrm{Hg}-\mathrm{C}$ bond unbroken (Gage, 1964).

\section{Apparatus and reagents}

The mercury vapour concentration meter used (Type E.3472, Hendrey Relays, Slough, Bucks) differed from 


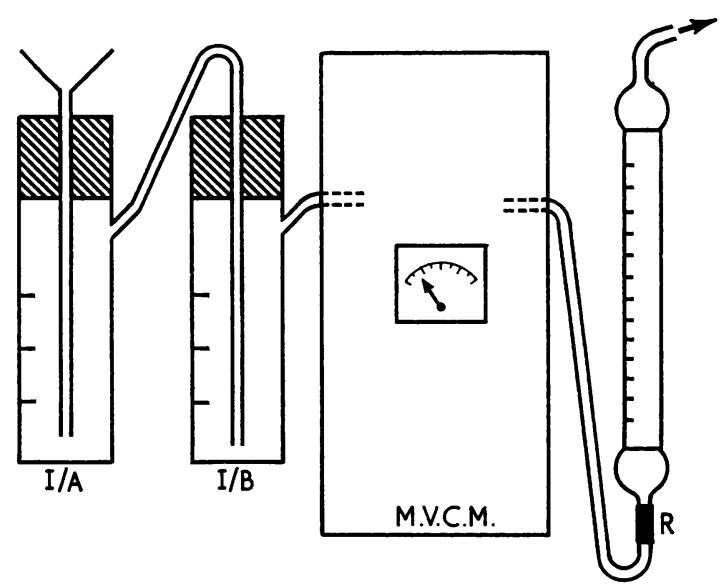

FIG. 1. Schematic diagram of apparatus. I/A and I/B = impingers; M.V.C.M. = mercury vapour concentration meter; $\mathrm{R}=$ rotameter.

that described by Brooks and Holmes (1958) in having its ammeter calibrated in units of mercury concentration in the gas cell. It was modified to get a constant and controlled air flow by substituting a water pump for the original fan. The water pump was connected by polyvinyl tubing through a calibrated rotameter with the outlet of the gas cell. To protect the rotameter against mercury vapour, the adjoining end of the tubing was filled with hopcalite (Hopkins and Williams) and loosely plugged with cotton wool.

The inlet of the gas cell was connected by polyvinyl tubing, approximately $20 \mathrm{~cm}$. in length, with two Midget impingers of $30 \mathrm{ml}$. (length $11.5 \mathrm{~cm}$.; diameter $2.5 \mathrm{~cm}$.). In order to decrease the resistance the inlet tubes of the impingers had no nozzle and had an inner diameter of $4 \mathrm{~mm}$. The first impinger (Fig. 1; I/A) served as a reaction vessel. The outside end of its inlet tube was attached to a small funnel. The second impinger (Fig. 1; I/B) served as a liquid trap to protect the gas cell against contamination if by accident some liquid was sucked out from the reaction vessel.

\section{Reagents}

All the reagents (BDH Chemicals), if not otherwise stated, were of analytical grade, and all the solutions were made up with glass distilled water. (a) Mercury stock solution: $0.6767 \mathrm{~g}$. $\mathrm{HgCl}_{2}$ was made up to $1,000 \mathrm{ml}$. with $5 \%$ $\mathrm{H}_{2} \mathrm{SO}_{4}$. (b) Mercury standard solution: $1.0 \mathrm{ml}$. of the stock solution was made up to $1,000 \mathrm{ml}$. with distilled water containing $9 \cdot 0 \mathrm{~g}$. $\mathrm{NaCl}, 0.7545 \mathrm{~g}$. sodium ethylenediaminetetra-acetate, and $0.063 \mathrm{~g}$. L-cysteine hydrochloride (lab. reagent). The standard solution, $0.5 \mu \mathrm{g}$. $\mathrm{Hg} / \mathrm{ml}$., was divided in 50 to $100 \mathrm{ml}$. portions which were stored in glass-stoppered flasks. Its concentration remained constant for at least three months. (c) Cysteine solution: $1 \mathrm{~g}$. L-cysteine hydrochloride was dissolved in $100 \mathrm{ml}$. $1.0 \mathrm{~N} \mathrm{HNO}_{3}$. (d) $10 \% \mathrm{HNO}_{3}$ solution (wv). (e) Solid stannous chloride $\left(\mathrm{SnCl}_{2}, 2 \mathrm{H}_{2} \mathrm{O}\right)$ was divided in approximately $100 \mathrm{mg}$. portions. $(f) 30 \% \mathrm{NaOH}$ solution (wv). (g) Tri- $n$-butyl phosphate.

\section{Procedure}

Approximately 30 minutes before a run the apparatus was switched on, and the filter control was set to 'Sample'. The airflow was adjusted to 2 litres/minute. Before use the filter control was set to zero and null point and the full scale was adjusted according to the operating instructions. Adjustment was repeated before every estimation. Scale sensitivity was selected according to the mercury content of the sample. High sensitivity, that is the ' $B$ ' scale, was used in the case of the blank or if the mercury content of the sample or the standard was not more than $0.2 \mu \mathrm{g}$. Low sensitivity, or the ' $A$ ' scale, was used if the mercury content was likely to be more than $0.2 \mu \mathrm{g}$.

After adjustment $2.0 \mathrm{ml}$. cysteine solution and 1 to $5 \mathrm{ml}$. urine or 0.05 to $2.0 \mathrm{ml}$. standard solution were pipetted into the reaction impinger (urine containing a sediment must be shaken before it is pipetted). To prevent foaming, one drop of tri- $n$-butyl phosphate was added. Finally, $100 \mathrm{mg}$. $\mathrm{SnCl}_{2}$ was added, and the impinger was filled to the $10 \mathrm{ml}$. mark with distilled water. The impinger was stoppered, the airflow was switched from zero to the sample, and four to five seconds later $2 \mathrm{ml} .30 \% \mathrm{NaOH}$ was added through the funnel to the sample. The mercury released and washed by the airstream through the gas cell resulted in the deflection of the needle on the scale.

In the work presented here the maximum deflection was used for the calculation of the mercury content of the sample, and this method proved to be satisfactory. However, if the photometer is connected with a recorder, the planimetric or gravimetric evaluation of the area under the curve can be used for calibration.

The blank usually gave readings not higher than 5 to $8 \mu \mathrm{g} . / \mathrm{m}^{3}$. A high reading showed that either the reagents or the impinger and connecting tubes were contaminated. To check the first possibility the airflow should be left on and the reagents added one by one to the sample. An upward deflection of the needle identifies the contaminated reagent. If the needle does not go back to the null point at all, except after switching the airflow from the sample to zero, contamination of the impingers or the connecting tubes should be suspected. If after switching again from zero to the sample the mercury concentration increases again in the gas cell, the diagnosis is confirmed.

A series of estimations could be made in the same reaction impinger without appreciable cross-contamination. It was quite satisfactory to dissolve any $\mathrm{SnCl}_{2}$ precipitated on the wall of the impinger with $10 \% \mathrm{H}_{2} \mathrm{SO}_{4}$, and to wash the impinger and the 
inlet tube with running water. Actually it was more convenient and reliable to use the same impinger for a series of estimations than to check every new one for contamination.

Time curve of mercury volatilization and efficiency of reaction

To test the time curve of the mercury volatilization and the efficiency of the reaction, samples containing mercury labelled with ${ }^{203} \mathrm{Hg}$ (Radiochemical Centre, Amersham, Bucks) were tested. The reaction was carried out as usual with $1 \mathrm{ml}$. standard solution labelled with $30 \mathrm{nCi}{ }^{203} \mathrm{Hg}$ and mixed with $5 \mathrm{ml}$. human urine, and the mercury concentration in the gas cell was recorded by a Honeywell Recorder (Honeywell Controls Ltd.) attached to the photometer. In some cases the mercury liberated from the samples was absorbed by a hopcalite absorber (Magos, 1966) attached to the outlet of the impinger. The hopcalite absorber was immersed into the well of the scintillation detector (Detector N664B) through which a scaler (N610A, Ekco Electronics Ltd.) was connected with the recorder. To move the air from the impinger to the hopcalite absorber a water pump was used, and the airflow was metered by a rotameter.

Figure 2 compares the two curves obtained. It can be seen that by the time the concentration in the gas cell had reached its peak, about $70 \%$ of the mercury had been released from the sample. In the next 10 seconds a further $10 \%$ was released, and by the time the concentration in the gas cell had returned to zero about $95 \%$ of the mercury had volatilized from the sample. The fraction of the mercury which did not volatilize was the same from standard solutions alone or mixed with urine, or from urine from rats pretreated with labelled

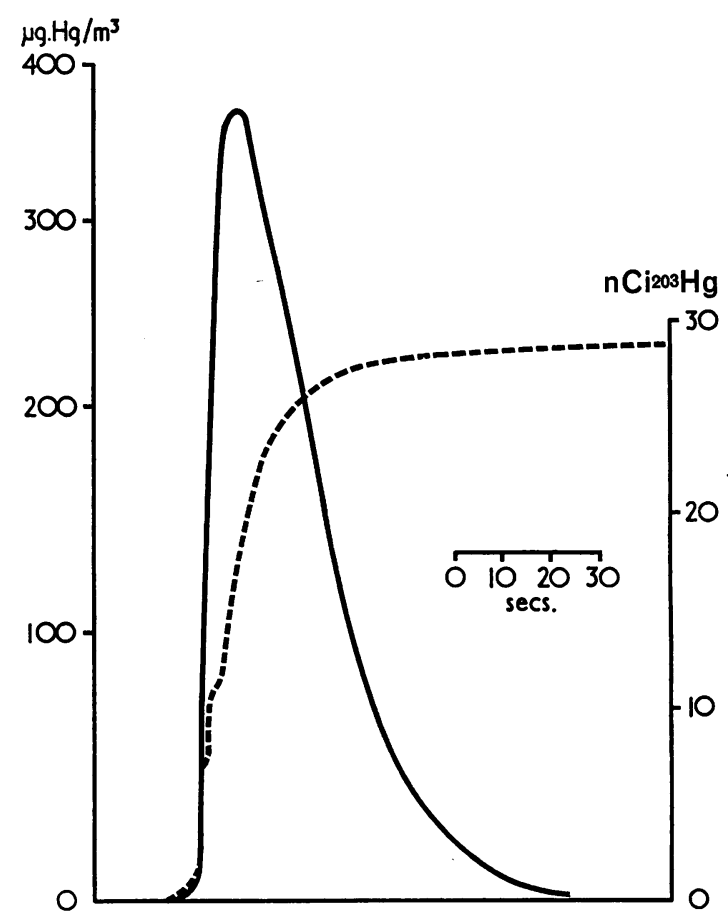

FIG. 2. Time curve of release of mercury from samples containing mercury labelled with $30 \mathrm{nCi}{ }^{203} \mathrm{Hg}$ : ( $\left.\longrightarrow\right)$ mercury concentration in gas cell; $(---)$ absorption of ${ }^{203} \mathrm{Hg}$ in a hopcalite absorber attached to outlet of reaction impinger.

mercury. In experiments with ${ }^{203} \mathrm{Hg}$ it was found that $4.7 \%$ (S.D. $\pm 1 \cdot 13, n=12$ ) of the total mercury had not reacted.

TABLE 1

Results of Standard Determinations of Mercury

\begin{tabular}{|c|c|c|c|c|c|c|c|c|}
\hline \multirow[t]{2}{*}{$\begin{array}{c}\text { Mercury } \\
\quad(\mu g .)\end{array}$} & \multirow[t]{2}{*}{$\begin{array}{l}5 \text { ml. urine } \\
\text { added }\end{array}$} & \multirow[t]{2}{*}{$\begin{array}{c}\text { No. of } \\
\text { determinations }\end{array}$} & \multicolumn{3}{|c|}{$\begin{array}{c}\text { Peak concentration of } \\
\text { mercury in gas cell } \\
\text { corrected to blank }\left(\mu \mathrm{g} . / \mathrm{m} .^{3}\right)\end{array}$} & \multicolumn{3}{|c|}{$\begin{array}{l}\text { Peak concentration: mercury } \\
\text { content of sample }\end{array}$} \\
\hline & & & Mean & Max. & Min. & Mean & Max. & Min. \\
\hline \multirow[t]{2}{*}{$\begin{array}{l}0.025 \\
0.050 \\
0 \cdot 100 \\
0 \cdot 100 \\
0.200 \\
0.300 \\
0.300 \\
0.500 \\
0.750 \\
1.000 \\
1.000\end{array}$} & $\begin{array}{l}- \\
- \\
\overline{+} \\
- \\
\overline{+} \\
- \\
- \\
- \\
+\end{array}$ & $\begin{array}{r}6 \\
6 \\
6 \\
6 \\
6 \\
10 \\
6 \\
6 \\
12 \\
8 \\
12 \\
6\end{array}$ & $\begin{array}{r}16 \\
30 \\
59 \\
60 \\
122 \\
188 \\
185 \\
308 \\
462 \\
613 \\
625\end{array}$ & $\begin{array}{r}20 \\
32 \\
60 \\
62 \\
127 \\
185 \\
192 \\
320 \\
480 \\
650 \\
655\end{array}$ & $\begin{array}{r}14 \\
29 \\
56 \\
59 \\
117 \\
175 \\
175 \\
280 \\
435 \\
575 \\
615\end{array}$ & $\begin{array}{l}640 \\
600 \\
590 \\
600 \\
610 \\
626 \cdot 7 \\
616 \cdot 7 \\
616 \\
616 \\
613 \\
625\end{array}$ & $\begin{array}{l}800 \\
640 \\
600 \\
620 \\
635 \\
650 \\
640 \\
640 \\
640 \\
650 \\
650\end{array}$ & $\begin{array}{l}560 \\
580 \\
560 \\
590 \\
585 \\
583 \cdot 3 \\
583 \cdot 3 \\
560 \\
580 \\
575 \\
615\end{array}$ \\
\hline & & & & & & Mean 613.9 & & \\
\hline
\end{tabular}




\section{Standardization}

The maximum deflection of the needle was determined by liberating mercury from different volumes of standard solutions $(0.05$ to $2.0 \mathrm{ml}$.) with or without $5 \mathrm{ml}$. urine. In addition to the normal blank, the deflection caused by $5 \mathrm{ml}$. urine was also estimated. All the estimations were corrected for the blank. Table 1 shows that there was a linear relationship between the mercury content of the samples and the maximum deflection, and that the deviation from the mean was less than $\pm 10 \%$ in all cases except with $0.025 \mu \mathrm{g}$. Hg. The results also showed that urine did not affect the maximum deflection.

As a result of the linear relationship between the mercury content in the sample and the reading on the scale, the maximum deflection caused by $0.5 \mu \mathrm{g}$. Hg was used for calculation instead of the calibration curve. If $b$ is the blank, the maximum deflection of the unknown sample is $D_{x}$, and the maximum deflection caused by $0.5 \mu \mathrm{g}$. $\mathrm{Hg}$ is $\mathrm{D}_{\mathrm{b}}$, the mercury content of the sample is:

$$
\mu \mathrm{g} . \mathrm{Hg}=0.5\left[\mathrm{D}_{\mathrm{x}}-\mathrm{b}\right] /\left[\mathrm{D}^{\frac{1}{2}}-\mathrm{b}\right]
$$

and if the volume of the sample is $\mathrm{V} \mathrm{ml}$., the mercury concentration of the sample is:

$$
\mu \mathrm{g} . \mathrm{Hg} / \mathrm{l} .=500\left[\mathrm{D}_{\mathrm{x}}-\mathrm{b}\right] / \mathrm{V}\left[\mathrm{D}_{\frac{1}{2}}-\mathrm{b}\right]
$$

During a three-month period the scale was tested at least three times a weèk. When the equipment was kept in the laboratory and was not subjected to sudden temperature changes, the shift in the calibration curve which occasionally appeared was never more than $\pm 10 \%$. Such shifts were systematic and did not influence the linearity of the calibration curve. However, to eliminate systematic errors the scale should be tested after the blank and before the urine estimations, and at least every hour during the work using $1.0 \mathrm{ml}$. standard solution.

\section{Mercury estimations in urine containing labelled mercury}

To check the reliability of the method two female rats of Porton Wistar strain weighing $220 \mathrm{~g}$. were injected intramuscularly with $100 \mu \mathrm{g}$. $\mathrm{Hg}$ as $\mathrm{HgCl}_{2}$ labelled with ${ }^{203} \mathrm{Hg}$ of known activity. The rats were placed in metabolic cages and urine was collected. Table 2 shows that the mercury concentration in the urine estimated with the method differed less than $10 \%$ from the concentration calculated from radioactivity.

However, when the estimation was repeated one week later on the same urine samples, the difference was significantly higher. The increase in the proportion of mercury resisting volatilization was probably the result of bacterial contamination. This undesired effect could be prevented by adding $0.1 \mathrm{ml}$. concentrated $\mathrm{HCl}$ (BDH Chemicals Ltd.) to every $10 \mathrm{ml}$. urine. Figure 3 shows the results of
TABLE 2

Estimation of Mercury in URINe of Rats Pretreated with Mercuric Chloride of KNOWN

\begin{tabular}{|c|c|c|c|}
\hline \multirow{2}{*}{$\begin{array}{l}\text { Volume of } \\
\text { urine }(\mathrm{ml} .)\end{array}$} & \multicolumn{2}{|c|}{ Results given by the method } & \multirow{2}{*}{$\begin{array}{l}\text { Hg conc. in } \\
\text { sample } \\
\text { calculated } \\
\text { from } \\
\text { radioactivity } \\
(\mu g . / l .)\end{array}$} \\
\hline & $\begin{array}{l}\text { Mercury in } \\
\text { sample } \\
(\mu g .)\end{array}$ & $\begin{array}{c}\text { Mercury conc. } \\
\text { in sample } \\
(\mu g . / l .)\end{array}$ & \\
\hline 1 & $\begin{array}{l}0 \cdot 345 \\
0 \cdot 355\end{array}$ & $\begin{array}{l}345 \\
355\end{array}$ & 373 \\
\hline 2 & $\begin{array}{l}0.740 \\
0.755\end{array}$ & $\begin{array}{l}370 \\
377\end{array}$ & \\
\hline 3 & $\begin{array}{l}1.050 \\
1.090\end{array}$ & $\begin{array}{l}350 \\
361\end{array}$ & \\
\hline
\end{tabular}
SPECIFIC ACTIVITY

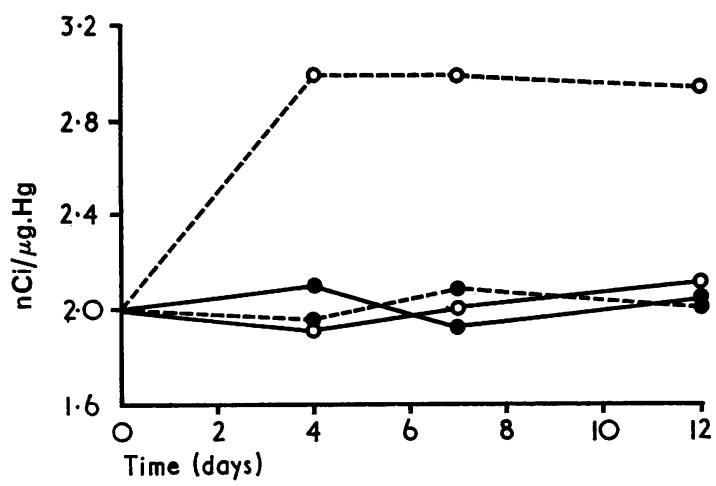

FIG. 3. Change of estimated specific activity $\left({ }^{203} \mathrm{Hg}\right)$ of human urine $(-)$ and rat urine $\left(-{ }_{-}\right)$without $\mathrm{HCl}(\mathrm{O})$ or with $0.1 \mathrm{ml}$. $\mathrm{HCl}$ added to every $10 \mathrm{ml}$. of urine (O). Estimated specific activity equals radioactivity of urine corrected to decay divided by mercury content estimated by the method.

experiments in which human and rat urines were given labelled mercury in a concentration of $150 \mu \mathrm{g}$. $\mathrm{Hg} /$ litre. The urines were kept in glass-stoppered bottles at room temperature with and without $\mathrm{HCl}$ and their radioactivities were corrected for decay, and their mercury concentrations were estimated at intervals. As the corrected specific activity must remain constant, an increase in the apparent specific activity indicates that less mercury was volatilized. It was found (Fig. 3) that the specific activity of the untreated rat urine increased during the first four days by about $50 \%$, indicating that about one-third of the mercury in the sample was converted to a form which resisted the reaction. The specific activities of the urines treated with $\mathrm{HCl}$ and of the 
untreated human urine changed very little, and their specific activities fluctuated within $\pm 5 \%$ of the initial values. The lack of change of specific activity in the untreated human urine was probably due to the absence of massive bacterial infection.

As bacterial contamination might result in loss of mercury by volatilization (Magos, Tuffery, and Clarkson, 1964), or might render some of the mercury unreactive, urine samples which are not tested on the day of collection must be preserved either by freezing or by the addition of $0.1 \mathrm{ml}$. concentrated $\mathrm{HCl}$ per $10 \mathrm{ml}$. urine. Toluene which absorbs light in the ultraviolet cannot be used for preservation.

\section{Mercury estimation in urine of workers exposed to} mercury

In a laboratory where urinary mercury estimations are carried out routinely, 68 urine samples were tested by this method and by the method of Kopp and Keenan (1963). The mercury concentration in the urine samples ranged from $3 \cdot 3 \mu \mathrm{g}$./l. to 2,600 $\mu \mathrm{g}$./l. when estimated with the method of Kopp and Keenan (1963). Of the 68 samples tested, the difference between the results given by the two methods was either between 0 and $30.0 \mu \mathrm{g}$. $\mathrm{Hg} / \mathrm{l}$. or not more than $10 \%$ in 45 cases $(67.2 \%)$. In a further 11 cases $(16.2 \%)$ the difference was between 11 and $20 \%$, and only in three cases $(4.4 \%)$ was the difference more than $30 \%$. The urines were not stored after the estimations, so that it was not possible to check which of the two methods was responsible for this difference. In contrast to the method of Kopp and Keenan (1963), the method presented here does not involve steps needing special precautions, and it seems reasonable to suppose that in the course of routine work Kopp and Keenan's method provides more opportunities for contamination or loss than our method.

Figure 4 shows that the results obtained by the two methods did not differ systematically. Only those results which had a mercury concentration of not more than $600 \mu \mathrm{g}$./l. are shown. Higher mercury concentrations give similar plus-minus differences.

\section{Mercury estimation in other biological samples}

Rats treated with $100 \mu \mathrm{g} .{ }^{203} \mathrm{Hg}$ as $\mathrm{HgCl}_{2}$ were killed 24 hours after the injection. Their kidneys were removed and homogenized in $1 \%$ sucrose. The mercury content in $0.2 \mathrm{ml} .10 \%$ homogenate estimated in six parallel samples gave a mean value of $0.56 \mu \mathrm{g} . / 0.2 \mathrm{ml}$. (S.D. \pm 0.02 ) in good agreement with the $0.55 \mu \mathrm{g}$. $\mathrm{Hg} / 0.2 \mathrm{ml}$. estimated from the radioactivity.

Blood samples were also tested, but the standard procedure with blood always recovered about 20 to $25 \%$ less mercury than was actually present. From stronger acid the recoveries could be increased significantly. After the blood had been mixed with

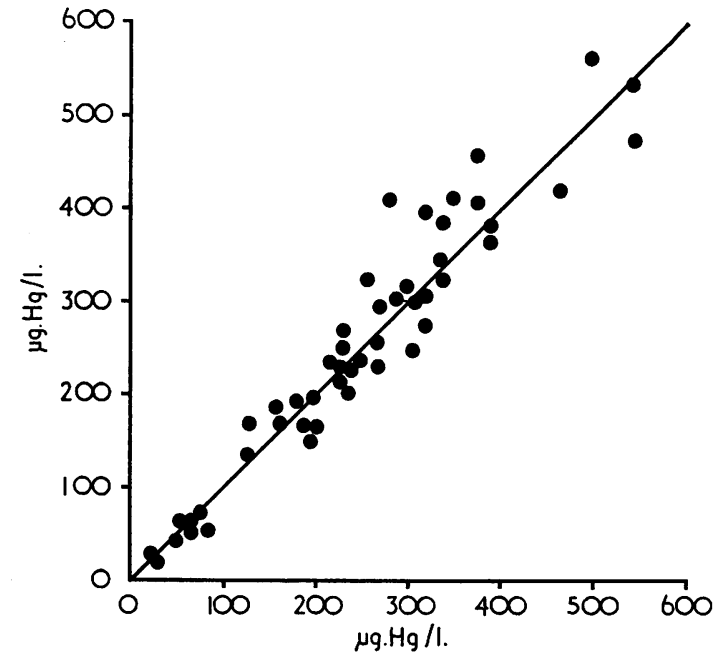

FIG. 4. Urinary mercury concentration of workers exposed to metallic mercury estimated by the method presented here (abscissa), and plotted against results given by the method of Kopp and Keenan (1963) (ordinate).

TABLE 3

Estimation OF Mercury in BloOd

$(1 \mathrm{ml}$. blood was mixed with different volumes of standard solution)

\begin{tabular}{|c|c|c|c|}
\hline Mercury added ( $g)$. & \multicolumn{3}{|c|}{ Mercury estimated $(\mu g)}$. \\
\hline 0.05 & 0.047 & 0.049 & 0.054 \\
\hline $0 \cdot 10$ & 0.090 & 0.094 & 0.098 \\
\hline 0.20 & $0 \cdot 193$ & 0.195 & 0.201 \\
\hline 0.50 & 0.470 & 0.480 & 0.486 \\
\hline 1.00 & 0.930 & 0.965 & 1.000 \\
\hline
\end{tabular}

the cysteine solution, $2 \mathrm{ml} .10 \% \mathrm{HNO}_{3}$ was added, and after this the normal procedure was followed. Table 3 shows the results obtained with heparinized rabbit blood when $1 \mathrm{ml}$. blood was mixed with different volumes of standard solutions and the modified estimation was carried out. The actual and estimated amounts agreed within $10 \%$, but as the recoveries averaged about $95 \%$ it seemed best to increase the concentrations found in blood by approximately $5.0 \%$.

\section{Comments}

The method presented here is rapid and needs no special skill, and its accuracy compares favourably with other more tedious methods. As an estimation can be carried out within two minutes, and the same time is needed to check the few reagents for mercury contamination, the possibility of finding an extremely 
high blank value only after the completion of a whole series of estimations is non-existent with this method. The only factor which matters is that the airflow must be kept constant. This simplicity makes it very suitable for use in a routine laboratory.

The authors wish to thank Mr. R. Lock for technical assistance, and Hendrey Relays Ltd. for lending the mercury vapour concentration meter.

\section{References}

Brooks, R. O. R., and Holmes, A. (1958). The Control of Mercury Metal in the Laboratory. AERE MED/R 2350, Atomic Energy Research Establishment, Harwell, Berkshire.
Gage, J. C. (1964). Distribution and excretion of methyl and phenyl mercury salts. Brit. J. industr. Med., 21, 197-202.

Jacobs, M. B., Yamaguchi, S. Goldwater, L. J., and Gilbert, H. (1960). Determination of mercury in blood. Amer. industr. Hyg. Ass. J., $21,475-480$.

Kopp, J. F., and Keenan, R. G. (1963). Determination of submicrogram quantities of mercury in urine by ion exchange separation. Ibid., 24, 1-10.

Kudsk, F. N. (1965). Determination of mercury in dithizone extracts by ultra-violet photometry. Scand. J. clin. Lab. Invest., 17, 171-177.

Lindström, O. (1959). Rapid microdetermination of mercury by spectrophotometric flame combustion. Analyt. Chem., 31, 461-467.

Magos, L. (1966). Radiochemical determination of metallic mercury vapour in air. Brit. J. industr. Med., 23, 230-236.

- Tuffery, A. A., and Clarkson, T. W. (1964). Volatilization of mercury by bacteria. Ibid., 21, 294-298.

Monkman, J. L., Maffett, P. A., and Doherty, T. F. (1956). The determination of mercury in air samples and biological materials. Amer. industr. Hyg. Ass. Quart., 17, 418-420.

Received for publication August 6, 1968. 